\title{
Review Article \\ Hazardous Effects of Titanium Dioxide Nanoparticles in Ecosystem
}

\author{
Syed Niaz Ali Shah, ${ }^{1,2}$ Zahir Shah, ${ }^{3,4}$ Muzammal Hussain, ${ }^{3}$ and Muzaffar Khan ${ }^{4}$ \\ ${ }^{1}$ Department of Chemistry, Quaid-i-Azam University, Islamabad, Pakistan \\ ${ }^{2}$ Department of Chemistry, Tsinghua University, Beijing 100084, China \\ ${ }^{3}$ Guangzhou Institutes of Biomedicine and Health, Chinese Academy of Sciences, 190 Kaiyuan Avenue, \\ Science Park, Guangzhou 510530, China \\ ${ }^{4}$ Department of Biochemistry, Faculty of Biological Sciences, Quaid-i-Azam University, Islamabad, Pakistan
}

Correspondence should be addressed to Syed Niaz Ali Shah; niazalianalyst@gmail.com and Zahir Shah; zahir@gibh.ac.cn

Received 23 December 2016; Accepted 8 February 2017; Published 8 March 2017

Academic Editor: Muataz A. Atieh

Copyright (C) 2017 Syed Niaz Ali Shah et al. This is an open access article distributed under the Creative Commons Attribution License, which permits unrestricted use, distribution, and reproduction in any medium, provided the original work is properly cited.

\begin{abstract}
Although nanoparticles (NPs) have made incredible progress in the field of nanotechnology and biomedical research and their applications are demanded throughout industrial world particularly over the past decades, little is known about the fate of nanoparticles in ecosystem. Concerning the biosafety of nanotechnology, nanotoxicity is going to be the second most priority of nanotechnology that needs to be properly addressed. This review covers the chemical as well as the biological concerns about nanoparticles particularly titanium dioxide $\left(\mathrm{TiO}_{2}\right) \mathrm{NPs}$ and emphasizes the toxicological profile of $\mathrm{TiO}_{2}$ at the molecular level in both in vitro and in vivo systems. In addition, the challenges and future prospects of nanotoxicology are discussed that may provide better understanding and new insights into ongoing and future research in this field.
\end{abstract}

\section{Introduction}

In the last decade, nanoscience has flourished a lot with rapidly advancing nanotechnology and its wider applications [1]. Nanomaterials (NMs) are being and have been exclusively developed and extensively used in a wide variety of products, including medicine, industry, personal care products $[2,3]$, cosmetics [4], sunscreens [5], toothpastes [6], paints, optics and electronics $[7,8]$, photocatalysts, antiultraviolet light agents [9], food packaging, medical devices, bandages, clothing, dental restoration material and water treatment facilities $[10,11]$, antibacterial agents [12], drug delivery systems, artificial organ, and tissue adhesives [13], and for cancer cells apoptosis under UV irradiations (Figure 1) [14]. Moreover, the nanoparticles (NPs) are eminent candidates to overcome drug resistance posed by microorganisms, a major challenge to scientific community [15]. Currently, more than 1000 products or product lines in market contain NPs [16, 17], and it has been estimated that the engineered NMs had reached 2.5 trillion US\$ annual profit by 2015 [17]. Nevertheless, the consequently increasing interactions of NPs with biological, chemical, and ecosystems have raised concerns regarding their general and occupational health and safety profiles. The NPs enter the environment and affect both biotic and abiotic components of the ecosystem [18], including human beings [19]. The aquatic ecosystem has also been contaminated with NPs and their negative impacts suppress the immune system of fish and invertebrates [10].

Among the NPs, titanium dioxide $\mathrm{NPs}\left(\mathrm{TiO}_{2} \mathrm{NPs}\right)$ are one of the most highly manufactured and widely used in the world [20]. $\mathrm{TiO}_{2}$ is a well-known semiconductor and a versatile compound that exists in three crystalline forms, anatase, rutile, and brookite $[14,21]$, which can only be activated with UV light due to its high band gap energy ( $3.0 \mathrm{eV}$ for rutile phase and $3.2 \mathrm{eV}$ for anatase phase). The anatase and rutile forms have natural and industrial importance, while the brookite is rarely used. Generally, anatase is more toxic than rutile and, unfortunately, being used abundantly $[21,22]$. Many researchers have contributed to the use of $\mathrm{TiO}_{2} \mathrm{NPs}$ in in vitro and in vivo systems. However, 


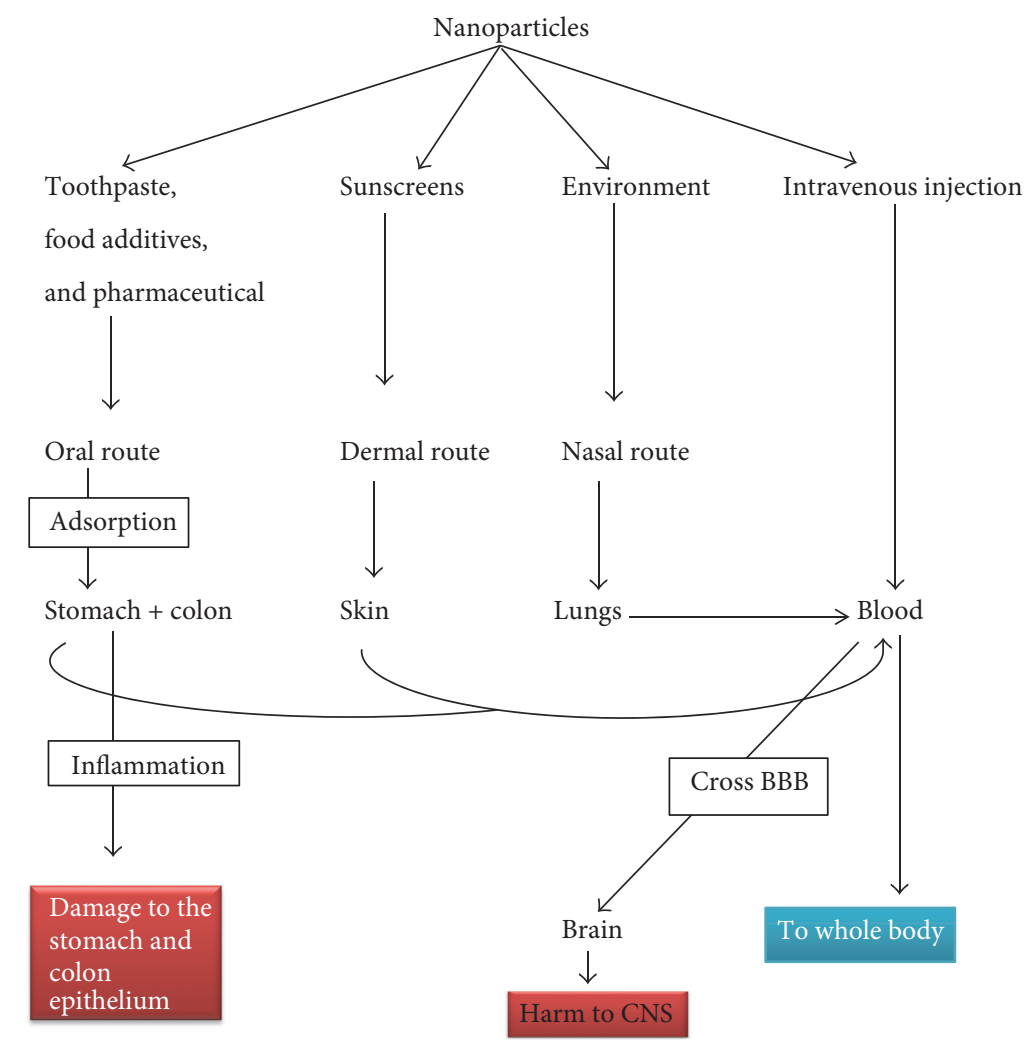

FIGURE 1: Nanoparticles containing products and their entrance ways into the biological system.

there is a lack of an overall evaluation of their toxicological effects in terms of harmful interactions with the biological and chemical systems and the environment. This review, therefore, specifically intends to provide a brief insight into the toxicological profile of $\mathrm{TiO}_{2} \mathrm{NPs}$ with respect to biological and ecosystems.

\section{Confliction about the Toxicological Impacts of $\mathrm{TiO}_{2} \mathrm{NPs}$}

$\mathrm{TiO}_{2}$ is known for long time as "the environmental white knight" due to its limited toxicity [23], inertness, and biocompatibility $[8,24]$. The lethal dose at $50 \%$ concentration $\left(\mathrm{LD}_{50}\right)$ of $\mathrm{TiO}_{2}$ is greater than $10 \mathrm{~g} / \mathrm{kg}$ [25], and it has been approved as a food additive since 1996 by the Food and Drug Administration (FDA). The FDA and Environmental Protection Agency (EPA) have specified $50 \mu \mathrm{g} / \mathrm{kg}$ body weight/day of nano- $\mathrm{TiO}_{2}\left(\mathrm{nTiO}_{2}\right)$ as safe dose for humans (Title 21, volume 1, revised as of April 1, 2014). Moreover, the European Commission's Scientific Committee on Food (SCF), the Joint Expert Committee on Food Additives of the Food and Agriculture Organization/World Health Organization (JECFA), and the European Food Safety Authority (EFSA)'s Scientific Panel on Food Additives, Flavorings, Processing Aids and Materials in Contact with Food have also approved the daily intake of nano- $\mathrm{TiO}_{2}$ in general food stuff. Looking from the perspective of potential adverse health effects, several experimental and epidemiological data have demonstrated that $\mathrm{TiO}_{2}$ is biologically inactive and physiologically inert, exhibiting relatively low toxicity, thus posing low risk to humans [26]. For example, in a study of chronic toxicity and carcinogenicity, a total of Fischer 344 rats and B6C3F1 mice at concentration of 0,25000 , and $50000 \mathrm{mg} \mathrm{TiO}_{2} / \mathrm{kg}$ diet for 103 weeks (2 years) showed no significant toxicity. In the same study, $\mathrm{TiO}_{2}$ coated mica at $0,1,2$, and $5 \%$ in Fischer 344 rats for 130 weeks (2 and half years) had no toxicological or carcinogenic effects [27]. Furthermore, the intraperitoneal injections (IP) of $\mathrm{TiO}_{2} \mathrm{NPs}(5 \mathrm{mg} / \mathrm{kg})$ for 14 days caused no significant adverse effects on mouse kidney [28]. Similarly, both the JECFA and EFSA evaluations of $\mathrm{TiO}_{2}$ showed that there is no absorption or tissue storage of $\mathrm{TiO}_{2}$, as well as no health hazard effects for occupational workers and public health by Material Safety Data Sheets (MSDS) [8]. In addition, the World Health Organization (WHO)'s Environmental Health states that "titanium compounds are poorly absorbed from the gastrointestinal tract, which is the main route of exposure for the general population" (WHO 1982), and they pose low hazard potential in mammals or aquatic species (Daphnia magna, Oncorhynchus mykiss) [29]. Keeping in view the above-mentioned data, it is obvious to accept that the $\mathrm{TiO}_{2}$ NPs are health friendly and nontoxic to biological environment.

Contrarily, the Scientific Committee on Consumer Safety (SCCS) has described the genotoxic, carcinogenic, and photosensitization behavior of $\mathrm{TiO}_{2}$ NPs (SCCS/1516/13), and several in vitro and in vivo studies have shown the adverse effects of $\mathrm{TiO}_{2}$ NPs in biological systems [30, 31]. Recently, Yin et al. [8] have shown that all the molecular sizes 
and crystal forms (anatase and rutile) of $\mathrm{nTiO}_{2}$ may cause phototoxicity [mainly caused by reactive oxygen species (ROS)] under UV irradiations [8] and exert acute toxicity in mice at different dosages of $0,324,648,972,1296$, 1944 , or $2592 \mathrm{mg} / \mathrm{kg}$ body weight [32]. ROS may further upregulate the inflammatory cytokines and apoptosis-related genes $[24,33,34]$, inhibit the heat shock proteins (HSP) $[24,35]$, and cause neuroinflammation (Figure 4) [36]. The small size (10-20 nm) $\mathrm{TiO}_{2}$ NPs may induce oxidative DNA damage, lipid peroxidation, and increased hydrogen peroxide $\left(\mathrm{H}_{2} \mathrm{O}_{2}\right)$ and nitric oxide production in BEAS-2B cells (human bronchial epithelial cell line) without photoactivation [35, 37]. Collectively, on the basis of above-described data, it seems that there is no clear-cut evidence regarding the safe dose of $\mathrm{TiO}_{2} \mathrm{NPs}$ and great attention is needed while dealing with these nanomaterials.

\section{Biological Perspective}

NPs, being the advent of nanotechnology, have great impact on the environment. Their production and consumption are increasing day by day, which ultimately has increased the contact chances of NPs with the environment. How do these NPs enter the biological system? What mechanism do they follow? And what are the consequences to the cell viability? To answer these questions, one needs to look very carefully while dealing with NPs in in vivo or in vitro studies as discussed in detail in the next sections.

3.1. Biological Uptake of $\mathrm{TiO}_{2} \mathrm{NPs}$ and Their Entry into the Human Cells. The cellular responses toward NPs depend not only on the properties of NPs, but also on the genetic, transcriptomic, and proteomic landscape of the target cells, imparting different cytotoxic and genotoxic outcomes in various cell types [38]. $\mathrm{TiO}_{2} \mathrm{NPs}$ enter the human body through several ways, including inhalation, ingestion (food stuffs and daily use materials), skin uptake (through skin lesions), and medical injections [39], and may be distributed to different body organs through circulatory system (Figure 1). After internalization, the $\mathrm{TiO}_{2}$ NPs interact with cytoplasmic proteome and bring posttranslational modifications, such as acetylation (A549 cells), by oxidative stress and other mechanisms (Figure 3) [39, 40]. They reach the periregion of nucleus, impede the function of endoplasmic reticulum, and block the nuclear pore or enter the nucleus. Inside the nucleus, they interact with DNA [35] and cause the upregulation of cytokines-, oxidative stress-, and apoptosisrelated genes [23, 24, 37]. Meanwhile, the defense system of the cell responds in such a way that the first-line defense is provided by superoxide dismutase (SOD) and catalase (CAT) against oxygen toxicity (ROS), and neutrophils participate against foreign particles (discussed in NETosis pathway in Section 3.2). The transformation of oxy-radicals occurs, such that superoxide radical ${ }^{\circ} \mathrm{O}_{2}{ }^{-}$is dismutated to $\mathrm{O}_{2}$ and $\mathrm{H}_{2} \mathrm{O}_{2}$ by catalytic activity of SOD enzyme and, then, CAT converts the $\mathrm{H}_{2} \mathrm{O}_{2}$ into water and oxygen. Oxidative stress (ROS) pathway is one of the mechanisms through which $\mathrm{TiO}_{2}$ and Ag NPs exert their toxic effects and disturb the life cycle of
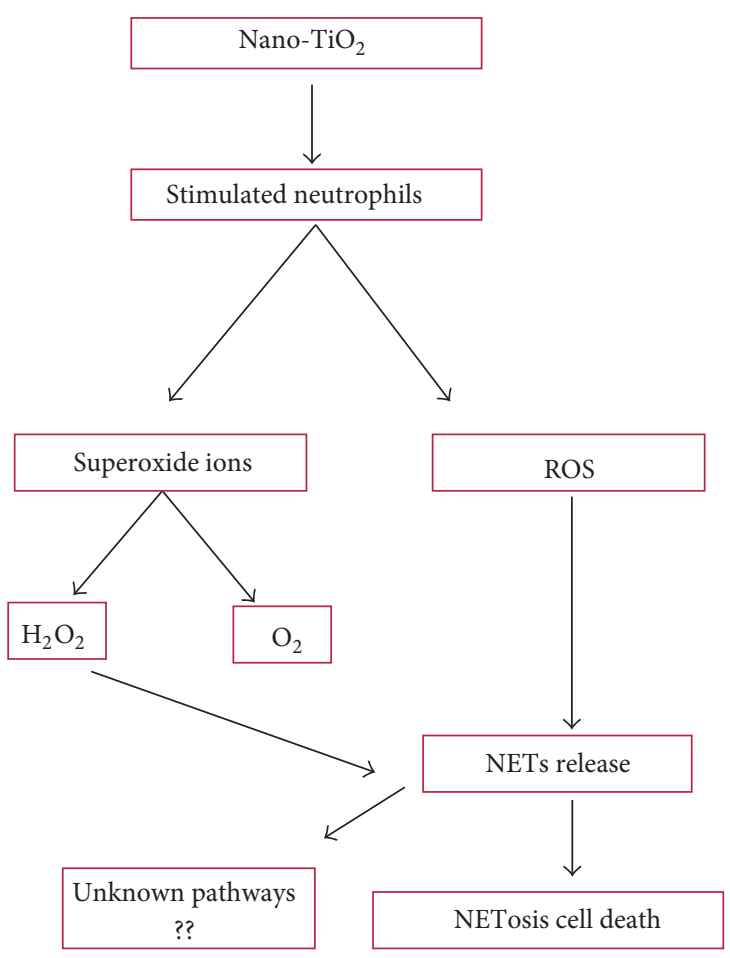

FIgURE 2: Nano-TiO 2 -induced NETosis cell death pathway.

Drosophila via enhanced ROS generation and DNA damage that lead to related adverse consequences (Figure 3) [7, 41]. In sertoli cells (testicular), the exposure of $\mathrm{TiO}_{2}$ NPs (2.5, 5 , or $10 \mathrm{mg} / \mathrm{kg}$ body weight) may cause severe testicular oxidative damage, apoptosis, ROS generation, and lipid peroxidation. $\mathrm{TiO}_{2}$ NPs may also cause suppression of SOD, CAT, glutathione peroxidase (GPx), glutathione $\mathrm{S}$ epoxide transferase (GST), glutathione reductase (GR), Cytochrome P450, Family 1, Subfamily B, Polypeptide 1 (Cyp1b1), carbonic anhydrase III (Car3), Bcl-2, acetyl-coenzyme A acyltransferase 2 (Acaa2), and Axin upregulated 1 (Axud1) in mouse testis, while enhancing the expression of apoptotic genes in mouse testis [42]. Moreover, the reverse correlation between ROS generation and reduction of glutathione (GSH) in human hepatocellular carcinoma cell line (SMMC-7721), rat hepatocarcinoma cell line (CBRH-7919), human liver cell line (HL-7702), and rat liver cell line (BRL-3A) has shown the toxicity of $\mathrm{TiO}_{2}$ NPs [13].

3.2. NETosis Pathway. Neutrophils, the first line of immune defense, have the ability to extrude their DNA (either mitochondrial or nuclear) along with bactericidal, fungal, and protozoal pathogen molecules, thus creating neutrophils extracellular traps (NETs) and releasing them to the extracellular environment. The NETosis pathway is elicited by respiratory burst and ROS generation, causing release of NETs due to formation of superoxide ions. The $\mathrm{H}_{2} \mathrm{O}_{2}$ in phagosome consequently leads to NETs release and NETosis via triggering of the downstream signaling pathways (Figure 2). Exposure of neutrophils to $\mathrm{nTiO}_{2}$ may lead to an increased oxidative burst that coincides with NETs release 


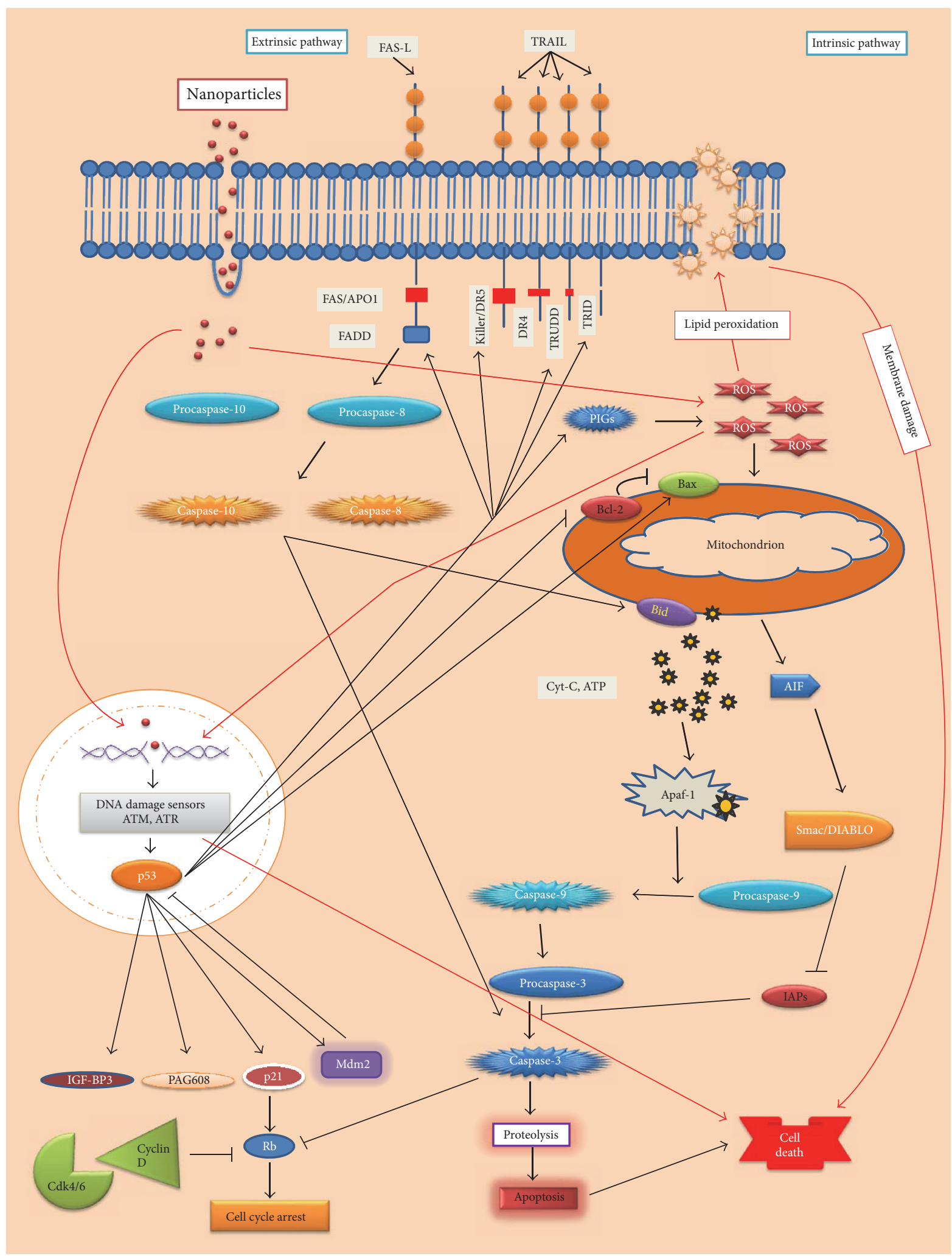

FIgure 3: The apoptosis induced by $\mathrm{TiO}_{2} \mathrm{NPs}$. The $\mathrm{TiO}_{2}$ NPs-induced apoptosis mostly follows the intrinsic pathway. TiO $\mathrm{NPs}_{2}$ enter the cell, induce ROS generation, and then enter the nucleus causing DNA damage. The DNA damage is sensed by sensor proteins (ATM/ATR) as a consequence of which p53 is upregulated, which further activates Bax (promoter of apoptosis) and inhibits Bcl2 (inhibitor of Bax). 


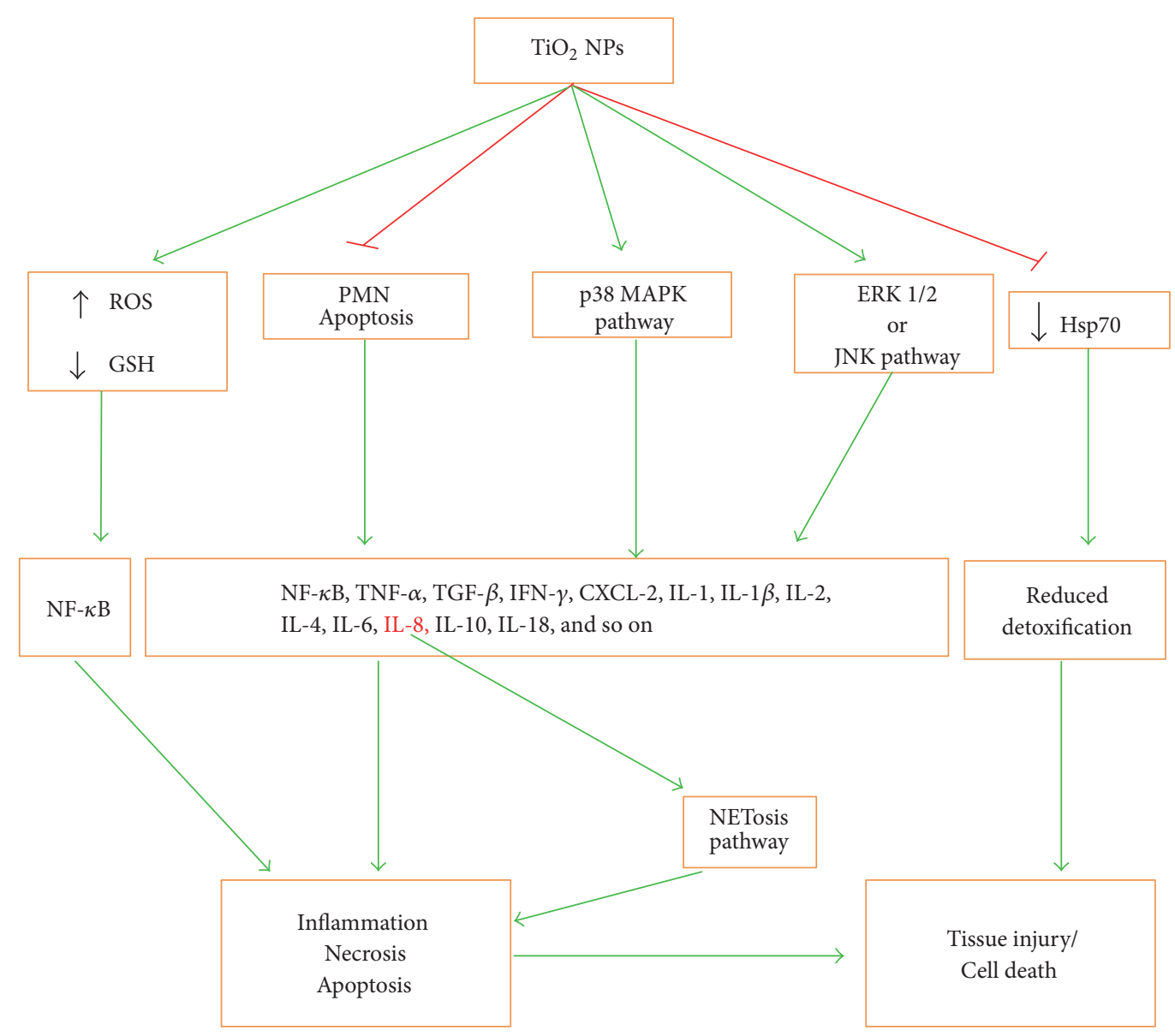

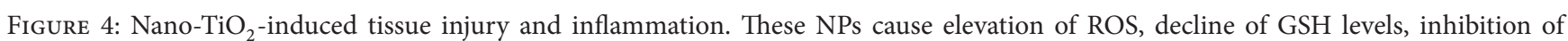
PMN apoptosis, and tyrosine phosphorylation of p38MAPK and ERK1/2 or JNK. All these induce the production of different inflammatory cytokines that in turn lead to inflammation and consequent necrosis or apoptosis mechanism of cell death. Decreased detoxification due to CYP1A and HSP70 decline also leads to tissue injury or cell death.

[43]. The NETosis is often accompanied by cell death in order to control and limit extracellular infections, which may otherwise cause complicated human diseases, including sepsis and autoimmune disorders $[44,45]$.

3.3. Apoptosis Mediated by $\mathrm{TiO}_{2} \mathrm{NPs}$. Generally, cells remain under constant threats from the cytotoxic and mutagenic effects of DNA damaging agents comprising endogenous (e.g., ROS) and exogenous (such as UV light, ionizing radiations, and other agents like chemicals in foodstuffs, water, or air) or both. Upon DNA damage, the cells undergo either DNA repair or cell cycle arrest leading to apoptosis [46]. Apoptosis is the best described mechanism through which NPs may exert their toxic effects inducing (a) an intrinsic pathway, mediated by mitochondria, or (b) an extrinsic pathway, mediated by death receptors.

$\mathrm{TiO}_{2}$ NPs have been shown to induce apoptosis via intrinsic pathway in human bronchial epithelial cell line (BEAS$2 B$ ), independent of caspase $8 / \mathrm{t}-\mathrm{Bid}$ (involved in extrinsic pathway), by enhancing ROS level and proinflammatory responses $[28,33]$. During this pathway mitochondrial membrane permeability is enhanced because of caspase- 3 release and subsequent PARP cleavage and release of cytochrome C, followed by induction of caspase- 9 and caspase-3 (effector caspases) of apoptosis-inducing factor. The genotoxic effect of $\mathrm{TiO}_{2} \mathrm{NPs}$ upregulates p53 gene that promotes the expression of Bax genes by suppressing Bcl-2 family regulator proteins, thus making an ease for opening the mitochondrial channels and release of cytochrome C (Figure 3) [7, 37, 47]. The accumulation of $\mathrm{TiO}_{2}$ NPs in mouse neurons manifests the apoptotic markers such as nuclear shrinkage and chromatin condensation [47]. Furthermore, $\mathrm{TiO}_{2}$ NPs may cause the upregulation of oxidative-stress-related genes, including heme oxygenase-1, thioredoxin reductase, glutathione- $S$-transferase, and cytokines such as interleukin(IL-) 1, IL-2, IL-4, IL-5, IL-6, IL-8, IL-10, IL-12, IL-18, and IL-1 $\beta$, transforming growth factor- (TGF-) $\beta$, tumor necrosis factor- (TNF-) $\alpha$, and interferon- (IFN-) $\gamma$ (Figure 4), which may cause inhibition of HSP70. The IL-8 gene expression is induced via p38 mitogen-activated protein kinase (MAPK) pathway and/or extracellular signal (ERK) pathway [24, 35]. Similarly, the intragastric exposure of $\mathrm{TiO}_{2}(2.5,5$, and $10 \mathrm{mg} / \mathrm{kg}$ ) in mouse may lead to their accumulation 
in kidneys, inducing necrosis and inflammatory responses (Figure 3) [24].

3.4. Phototoxicity and Genotoxicity. $\mathrm{TiO}_{2} \mathrm{NPs}$ induce phototoxicity upon UV irradiations. They have been shown to induce apoptosis by activating apoptosis-inducing factor (AIF) in human keratinocyte cells [48], as well as in retinal pigment epithelial cells (Figure 3) [2]. Moreover, $\mathrm{TiO}_{2} \mathrm{NPs}$ have been demonstrated to cause pericardial oedema and premature hatch of Japanese medaka (Oryzias latipes) embryos when treated with aqueous suspensions at 0 and $14 \mu \mathrm{g} / \mathrm{mL}$ [49].

The genotoxicity of $\mathrm{TiO}_{2}$ NPs attributes to ROS generation and oxidative stress in human epidermal cells, which elicits signal transduction pathways leading to apoptosis or cellular death [33]. They have been shown to induce DNA double-strand breakage in bone marrow and human amnion epithelial (WISH) cells, as well as in mice in a dose-dependent manner, leading to cell cycle arrest [50-52]. The induction of ROS may reduce NADH levels, impairing mitochondrial membrane potential $(\Delta \Psi \mathrm{m})$ and causing mitochondrial dysfunction [53]. The exposure of $\mathrm{TiO}_{2}$ and $\mathrm{Al}_{2} \mathrm{O}_{3}$ NPs may also cause genotoxic effects in Chinese hamster ovary after $24 \mathrm{~h}$ treatment [54]. The genotoxicity, apoptosis, and mitotic arrest are caused by both nano- and microparticles of $\mathrm{TiO}_{2}$ in various tissues of mice [4], as mentioned by SCCS in 2013 (SCCS/1516/13) (discussed in Section 2).

In human lymphocytes, $\mathrm{TiO}_{2} \mathrm{NPs}$ have been found genotoxic at a dose of $0.25 \mathrm{mM}$ probably by the lipid peroxidation mechanism and at $4 \mathrm{mM}$ to Allium cepa [55]. The viability of human epidermal cells was significantly decreased due to DNA damage, micronucleus formation, and reduction in glutathione [14]. They were readily uptaken by A549 cells (carcinomic human alveolar basal epithelial cells) in vitro. However, such rapid uptake was in contrast with a very low oral absorption in a differentiated Caco-2 monolayer system (human epithelial colorectal adenocarcinoma cells) and after oral gavage administration to rats [56]. The calculation of uptake, dispersion, and biological effects of ingested NMs is complicated in vivo due to interindividual differences in the composition, $\mathrm{pH}$, thickness of the mucus layer, gastrointestinal flora, and gastrointestinal passage time [57]. The in vitro studies of NPs interactions are unrealistic and may not indicate the actual fate of NPs, while in in vivo studies, the biological molecules are absorbed on the surface of NPs, changing their biokinetics and the consequent fate of the biomolecules in natural environment [58].

3.5. Neurotoxicity. Brain tissues are more susceptible to oxidative stress-induced damage because of high metabolic rate, cellular content of lipids, proteins, and extensive axonal and dendritic networks, and low levels of endogenous scavengers. After exposure of $\mathrm{TiO}_{2} \mathrm{NPs}$, the integrity of blood brain barrier (BBB) is badly affected due to persistence of NPs in endothelial cells or via infiltration of immune cells, resulting in breakdown of BBB. In an experimental study, the $\mathrm{TiO}_{2}$ NPs have been demonstrated to cause injury to neurons via JNK/p53-mediated-apoptosis and ROS generation, which activated downstream p53/p21 pathway, causing G2/M arrest in in vitro model of dopaminergic neurons ( $\mathrm{PC12}$ cell) (Figure 3) [21, 59]. In another study, the $\mathrm{TiO}_{2}$ NPs were found to enter the brain via olfactory bulb and reside in the hippocampus region, damaging mitochondria and inducing oxidative stress in rat and human glial cell lines [60]. The anatase nano- $\mathrm{TiO}_{2}$ are more toxic to neuronal cells than rutile [21]. Whether these findings have definite neurotoxic implications needs further investigations.

3.6. Respiratory Toxicity. The exposures of NMs via inhalation (occupational and/or environmental) may affect the respiratory tract, resulting in an increased risk of lung cancer, fibrosis, blockage of interalveolar areas, and presence of inflammatory cells $[17,61]$. The natural and engineered NPs penetrate the lungs through inhalation, reach different body organs via the blood circulatory system [51], and upregulate the inflammatory proteins (MIP and MCP) and genes of MHC class I via Th2-mediated pathway [62]. The IFN$\gamma$ is preferably released from Th1 cells and induces NPstriggered cellular immune response along with ROS production in macrophages. They also elicit the expression of GTPcyclohydrolase I (GCH-I) enzymes, which lead to formation of neopterin, and of indoleamine 2,3-dioxygenase (IDO) (first step is catalyzing enzyme in tryptophan breakdown by kynurenine pathway). The intratracheal exposure of $\mathrm{TiO}_{2}$ NPs in mouse may result in their substantial accumulation in lungs, causing bleeding and inflammation [34, 63]. The mutagenic potential of $\mathrm{TiO}_{2}$ NPs has been revealed by the treatment of pUC19/lacZ ${ }^{-}$plasmid with different concentrations of $\mathrm{TiO}_{2}$ NPs (average size $30.6 \mathrm{~nm}$ ) and subsequent transfection of $\mathrm{CaCl}_{2}$-induced competent $\mathrm{DH} 5 \alpha$ cells, which showed loss of transfection efficacy of the plasmid in comparison to untreated ones [64].

In a cytoplasmic proteome study involving human monocyte-derived macrophages, the abundancies of chloride intracellular channel protein 1 , cathepsin $\mathrm{D}$, and lysine acetylation were observed after exposure to $\mathrm{nTiO}_{2}$ [40]. Recently, Sheng et al. [65] have demonstrated the significant alterations in the expressions of 1041 genes involved in different types of processes, including immune/inflammatory responses, apoptosis, oxidative stress, stress responses, metabolic processes, ion transport, signal transduction, and cell proliferation/division and translation, in mice spleen [65].

$\mathrm{TiO}_{2}$ also caused lung cancer in rats after oral administration of 160 and $33 \mathrm{~nm}$ particles at doses of 40,200, and $1000 \mathrm{mg} / \mathrm{kg}$ body weight [4]. The ultrafine $\mathrm{TiO}_{2}\left(\mathrm{UF}-\mathrm{TiO}_{2}\right)$, less than $100 \mathrm{~nm}$ in diameter, induced pulmonary fibrosis, lung tumor, and genotoxicity in rats $[66,67]$. Similarly, the NMs may also cause damage to liver cells during cleansing of toxins and pollutants in body. Furthermore, the $\mathrm{TiO}_{2} \mathrm{NPs}$ may cause hepatotoxicity in human hepatocellular carcinoma cell line (SMMC-7721), human liver cell line (HL-7702), rat hepatocarcinoma cell line (CBRH-7919), and rat liver cell line (BRL-3A), which may be associated with changes in cell morphology, increased intercellular ROS production, and decreased GSH levels at $0.1-100 \mu \mathrm{g} / \mathrm{mL}$ [13].

3.7. Aquatic Nanotoxicity. The in vitro studies have raised concerns about the toxicity of $\mathrm{TiO}_{2}$ NPs in mammalian, but 
there are limited data on ecotoxicity to aquatic organisms. The heaping of NPs to sewage increases due to their excessive use in industry and commerce [68]. The engineered nanoparticles (ENPs) intermingle with various toxins, including metals in sediments and water phase, making agglomerates and resides [69], and causing damage to aquatic organisms [55]. The exposure of adult zebra fish to $1.0 \mathrm{mg} / \mathrm{L} \mathrm{TiO}_{2}$ (both NP and bulk) for 21 days has been shown to lower the number of viable embryos [70] and inhibit the growth of goldfish (Carassius auratus) [71]. Similarly, the exposure of $\mathrm{nTiO}_{2}$ suspensions (100 and $200 \mathrm{mg} / \mathrm{L}$ ) to carp (Cyprinus carpio) may cause a decrease in SOD, CAT, and POD, while inducing a significant increase in LPO levels in the liver [72]. The combined exposure of anatase and rutile NPs to freshwater microalgae, Chlorella sp., at $0.25,0.5$, and $1 \mathrm{mg} / \mathrm{L}$ under UV irradiations has been demonstrated to reduce the cell viability and chlorophyll content [22]. $\mathrm{TiO}_{2}$ has also adverse impacts on the survival, growth, and reproduction of $D$. magna. It has been determined that exposure of anatase $(21 \mathrm{~nm})$ particles is more toxic to D. magna as compared to anatase (250 nm) and rutile $(500 \mathrm{~nm})$ particles [73]. Therefore, the study of adverse effects of various NMs on aquatic species is necessary to assess their potential environmental hazardous effects.

\section{Interactions of NPs in Ecosystem}

The clean air is not only of scientific, environmental, and physiological importance but a basic need for living a healthy life. The chemicals and biological attacks may pose risk to human health and environment [74]. In this regard, the dangers of NPs to human health and environment have increased due to the prompt growth in nanotechnology. The adsorption of noxious pollutants on NPs has been extensively studied. In environment, the NPs always amalgamate with other pollutants. The interactions between conventional pollutants with NPs and their impact on environmental components are little considered. The heaping of NPs to sewage increases due to their excessive use in industry and commerce [68]. The chance of association of organic materials, including toxicants, increases with the aggregation of NPs in water. Hence, the bioavailability of these materials is altered. Thus, extra toxicological concerns are needed in presence of NPs [75].

The workers involved in the production of $\mathrm{TiO}_{2} \mathrm{NPs}$ may have significant risk on cytotoxicity response at relatively high airborne concentrations of anatase $\mathrm{TiO}_{2} \mathrm{NPs}$ [76]. Widespread use of $\mathrm{nTiO}_{2}$ may intensify the threat of combined exposure of $\mathrm{nTiO}_{2}$ with other environmental pollutants. The mixing of different compounds may bring astonishing toxic effects, even if the toxicities of the individual compounds are well known. For example, when bisphenol A (BPA) combines with $\mathrm{nTiO}_{2}$, it facilitates the movement of $\mathrm{nTiO}_{2}$ into exposed cells, causing synergistic toxicity by oxidative stress, inducing DNA double-strand breaks and micronuclei formation [77]. The growth inhibition of fresh water algae (Pseudokirchneriella subcapitata) was increased by the interaction of $\mathrm{Cd}$ (II) species with $\mathrm{TiO}_{2}$ [78]. Similarly, the adsorption of $\mathrm{Cd}(\mathrm{II})$ onto $\mathrm{nTiO}_{2}$ was enhanced by coating humic acid (HA) on $\mathrm{nTiO}_{2}$ [79]. The anatase NPs are superior sorbents than activated carbon and other metal oxide NPs
[80]. The $\mathrm{TiO}_{2}$ and $\mathrm{Al}_{2} \mathrm{O}_{3}$ NPs enter the Chinese hamster ovary (CHO-K1) cells through endocytosis and attack on lysosomal and mitochondrial activities, thus causing cytotoxicity and genotoxicity as well as a decrease in cell viability [54].

The hydroxylated fullerenes/C60 $(\mathrm{OH}) 24$ exert synergistic stimulative effect on genes related to circadian rhythm, vesicular transport, kinases, and immune responses in zebrafish embryos [81], while the presence of nitrite with $\mathrm{TiO}_{2}$ enhances the induction of apoptosis-related genes via NO signaling pathway [48].

\section{Chemical Perspective}

From chemical perspective, $\mathrm{TiO}_{2}$ NPs show phototoxic effects upon UVA irradiations. Upon photon energy absorption, the electrons of the NPs jump from valence band to the conduction band, leaving the valence band holes. Hydroxyl radicals $\left({ }^{\circ} \mathrm{OH}\right)$ are produced when valence band holes take electrons from water or hydroxyl ions and other ROS such as singlet oxygen $\left({ }^{1} \mathrm{O}_{2}\right)$ and superoxide $\left({ }^{\circ} \mathrm{O}_{2}{ }^{-}\right)$are also produced by different mechanisms. Free radicals $\left({ }^{\circ} \mathrm{OH}\right.$ and carbon centered free radicals) are also generated in dark. The generated ROS may be genotoxic or cytotoxic, affecting cell viability (Figure 3 ). Hence, $\mathrm{TiO}_{2} \mathrm{NPs}$ are toxic to living system both in the presence and absence of light via generation of free radicals [2].

\section{Effect of Exposure Time and Dose on Toxicity of $\mathrm{TiO}_{2}$ NPs}

The primary particle size (the size of particle at the time of injection) of $\mathrm{TiO}_{2} \mathrm{NPs}$ is not as important as that of secondary particle size (the size of particle after agglomeration) for in vivo toxicity. Likewise, the physicochemical characteristics and time of exposure of NPs before the toxicological study are important [82]. The dietary exposure of $\mathrm{nTiO}_{2}$ for 3 or 14 days may cause hazards to the terrestrial invertebrates [83]. Intratracheal instillation to rats with $0.5,5$, or $50 \mathrm{mg} / \mathrm{kg}$ of 5 , 21 , and $50 \mathrm{~nm} \mathrm{TiO}_{2}$ primary particles, respectively, has been demonstrated to exhibit dose-dependent toxic responses. In the same way, intraperitoneal injection of $\mathrm{TiO}_{2} \mathrm{NPs}(5 \mathrm{mg} / \mathrm{kg})$ for 14 days did not have considerable effect on mouse kidney and the nephric dysfunction; however at doses of 50,100, and $150 \mathrm{mg} / \mathrm{kg}$ body weight, it significantly induced inflammatory response and abnormal functions of kidney in mice.

Short-term exposure of $\mathrm{TiO}_{2}$ NPs may have low-tomedium ecological hazards on zebrafish [23]. Nano- $\mathrm{TiO}_{2}$ exposure for $3 \mathrm{~h}$ causes highest production of ROS in cytoplasm while at $24 \mathrm{~h}$ exposure ROS is only produced in perinuclear region due to aggregation [35].

Nano- $-\mathrm{TiO}_{2}$ accumulation occurs around the nucleus for up to 25 days in retinal pigment epithelial cells after a single low-level long-term exposure [2]. The cytotoxicity in normal liver and carcinomatous liver cells of either rat or human increases as the time of exposure increases, even a low concentration of $\mathrm{nTiO}_{2}$ may induce higher toxicity with increase in time of exposure [13]. In long-term exposure, $\mathrm{TiO}_{2} \mathrm{NPs}$ 
may cause pronounced adverse effect (growth inhibition and loss in liver weight) on zebrafish in time- and dose-dependent manner in vivo. It has also been shown that $\mathrm{TiO}_{2} \mathrm{NPs}$ exposure for 6 months to zebrafish may elicit pronounced toxic consequences like organ injury, behavior alterations, mortality, and organ distribution at higher concentration [23]. Furthermore, at long-term exposure, $\mathrm{TiO}_{2}$ accumulates in the cell and causes toxic effects which are not evident at short-term exposure [84]. Several cell lines exposed to higher concentrations $\left(100 \mu \mathrm{g} / \mathrm{mL}\right.$ of $\left.\mathrm{TiO}_{2}\right)$ may exhibit morphological changes such as cell shrinkage or nuclear condensation [35]. The exposure of differentiated murine J774.2 macrophages to $1 \mu \mathrm{g} / \mathrm{mL}$ concentration may have no considerable effects on cell proliferation, while at concentration $10 \mu \mathrm{g} / \mathrm{mL}$ it may exhibit significant cytotoxic effects [12]. Unnithan and colleagues have shown that fine nano$\mathrm{TiO}_{2}(\sim 20 \mathrm{~nm})$ at $40 \mathrm{mg} / \mathrm{kg}$ cause biochemical perturbations in Wistar rats [85]. Conclusively, the NPs even at their noncytotoxic doses may have pathophysiological concerns [28].

\section{Effect of Size and Shape on Toxicity of $\mathrm{TiO}_{2} \mathrm{NPs}$}

The major physicochemical properties to evaluate the toxicity are size, shape, surface area, phase, composition, coating, nature of surface, and agglomeration of NPs $[16,86]$. The size and surface area of NPs may be responsible for their toxicity, but most of the studies do not reveal the relationship between physiochemical characteristics of NPs and their toxicity [82]. For example, $25 \mathrm{~nm}$ anatase and $31 \mathrm{~nm}$ anatase/rutile show greater phototoxicity than $142 \mathrm{~nm}$ anatase and $214 \mathrm{~nm}$ rutile NPs [2]. All the sizes and crystal forms (anatase and rutile) of $\mathrm{TiO}_{2}$ NPs exert toxic (phototoxic) effects on human skin keratinocytes under UVA irradiations in a dosedependent way. The smaller size $\mathrm{nTiO}_{2}$ may cause greater cytotoxicity than larger size NPs, and anatase form may show more phototoxicity than rutile $[8,84]$. Furthermore, the NPs (rod and sphere) of smaller size show higher toxicity than larger particles. Moreover, the nanorods exhibit more toxicity than spherical particles having the same size and surface area, showing the contribution of shape toward cytotoxicity [16]. The $\mathrm{Ag}(20$ and $200 \mathrm{~nm})$ and $\mathrm{TiO}_{2}(21 \mathrm{~nm})$ NPs are significantly taken up by human epithelial, hepatic, and undifferentiated monocyte cells, resulting in decline of metabolic activation and cell death enhancement [87].

\section{Conclusion and Future Perspectives}

Concerning the biosafety of nanotechnology, nanotoxicity is going to be the second most priority of nanotechnology. The different responses toward the NPs in ecosystem may be very complex and diverse, involving a variety of parameters, demonstrating their difficult environmental fate [88]. In addition, the environmental hazards of ENPs can be documented by knowing their behavior and fate in the natural aquatic system [89].

To date no product (medicinal or food stuff) is available with 100 percent purity and efficiency, but for the safer use of nanosized particles with no or minimal hazardous effects on environment, the detailed understanding about their sources, interactions with environment, biodegradability, and possible risk assessment are utmost requirement prior to use. In addition, the interactions of NPs with biological molecules and their adverse effects need to be fully understood prior to their approval in clinical trials.

The cellular responses and toxicity produced by $\mathrm{TiO}_{2} \mathrm{NPs}$ depend on the surface/mass ratio, purity, crystallinity, surface reactivity, adsorbed groups, coatings, solubility, shape, size [7, 54], zeta potential, and dispersion or propensity to agglomerate or aggregate in different media [90]. These parameters need to be considered for the safer use of NMs. The undefined health and environmental features of $\mathrm{TiO}_{2}$ NPs due to its widespread use are necessary to be managed by a systematic, coherent, and tested foundation. Therefore, the regulatory health risk assessment of such particles may be mandatory for the safe use of NMs in consumer products and medicines, including the potential effects on reproduction and fertility.

$\begin{array}{ll}\text { Abbreviations } \\ \text { NMs: } & \text { Nanomaterials } \\ \text { NPs: } & \text { Nanoparticles } \\ \mathrm{TiO}_{2} \text { NPs: } & \text { Titanium dioxide NPs } \\ \mathrm{LD}_{50}: & \text { Lethal dose at } 50 \% \text { concentration } \\ \text { FDA: } & \text { Food and Drug Administration } \\ \text { EPA: } & \text { Environmental Protection Agency } \\ \text { nTiO } 2: & \text { Nano-TiO } \\ \text { SCF: } & \text { European Commission's Scientific } \\ & \text { Committee on Food } \\ \text { JECFA: } & \text { Joint Expert Committee on Food } \\ & \text { Additives of the Food and Agriculture } \\ & \text { Organization/World Health Organization } \\ \text { EFSA: } & \text { European Food Safety Authority } \\ \text { MSDS: } & \text { Material Safety Data Sheets } \\ \text { WHO: } & \text { World Health Organization } \\ \text { SCCS: } & \text { Scientific Committee on Consumer Safety } \\ \text { ROS: } & \text { Reactive oxygen species } \\ \text { HSP: } & \text { Heat shock proteins } \\ \text { H } \mathrm{O}_{2}: & \text { Hydrogen peroxide } \\ \text { SOD: } & \text { Superoxide dismutase } \\ \text { CAT: } & \text { Catalase } \\ \text { GPx: } & \text { Glutathione peroxidase } \\ \text { GST: } & \text { Glutathione S epoxide transferase } \\ \text { GR: } & \text { Glutathione reductase } \\ \text { NETs: } & \text { Neutrophils extracellular traps } \\ \text { TGF- } \beta: & \text { Transforming growth factor- } \beta \\ \text { TNF- } \alpha: & \text { Tumor necrosis factor- } \alpha \\ \text { IFN- } \gamma: & \text { Interferon- } \gamma \\ \text { MAPK: } & \text { Mitogen-activated protein kinase } \\ \text { AIF: } & \text { Apoptosis-inducing factor } \\ \text { BBB: } & \text { Blood brain barrier } \\ \text { IDO: } & \text { Indoleamine 2,3-dioxygenase } \\ \text { UF-TiO }: ~ & \text { Ultrafine TiO } \\ \text { ENPs: } & \text { Engineered nanoparticles } \\ \text { BPA: } & \text { Bisphenol A } \\ \text { HA: } & \text { Humic acid } \\ \text { CHO-K1: } & \text { Chinese hamster ovary } \\ & \end{array}$


- OH: Hydroxyl radicals

${ }^{1} \mathrm{O}_{2}$ : Singlet oxygen

$\cdot \mathrm{O}_{2}^{-}$: Superoxide.

\section{Competing Interests}

The authors declare no competing financial interests.

\section{Acknowledgments}

The authors thank all the researchers who contributed to their current understanding of hazardous effects of $\mathrm{TiO}_{2} \mathrm{NPs}$.

\section{References}

[1] D. M. Gonçalves and D. Girard, "Titanium dioxide $\left(\mathrm{TiO}_{2}\right)$ nanoparticles induce neutrophil influx and local production of several pro-inflammatory mediators in vivo," International Immunopharmacology, vol. 11, no. 8, pp. 1109-1115, 2011.

[2] K. Sanders, L. L. Degn, W. R. Mundy et al., "In vitro phototoxicity and hazard identification of nano-scale titanium dioxide," Toxicology and Applied Pharmacology, vol. 258, no. 2, pp. 226236, 2012.

[3] K. Khosravi, M. E. Hoque, B. Dimock, H. Hintelmann, and C. D. Metcalfe, "A novel approach for determining total titanium from titanium dioxide nanoparticles suspended in water and biosolids by digestion with ammonium persulfate," Analytica Chimica Acta, vol. 713, pp. 86-91, 2012.

[4] L. P. Sycheva, V. S. Zhurkov, V. V. Iurchenko et al., "Investigation of genotoxic and cytotoxic effects of micro- and nanosized titanium dioxide in six organs of mice in vivo," Mutation Research/Genetic Toxicology and Environmental Mutagenesis, vol. 726, no. 1, pp. 8-14, 2011.

[5] D. M. Gonçalves, S. Chiasson, and D. Girard, "Activation of human neutrophils by titanium dioxide $\left(\mathrm{TiO}_{2}\right)$ nanoparticles," Toxicology in Vitro, vol. 24, no. 3, pp. 1002-1008, 2010.

[6] B. Li, R. Hu, Z. Cheng et al., "Titanium dioxide nanoparticles relieve biochemical dysfunctions of fifth-instar larvae of silkworms following exposure to phoxim insecticide," Chemosphere, vol. 89, no. 5, pp. 609-614, 2012.

[7] S. J. Kang, B. M. Kim, Y. J. Lee, S. H. Hong, and H. W. Chung, "Titanium dioxide nanoparticles induce apoptosis through the JNK/p38-caspase-8-Bid pathway in phytohemagglutininstimulated human lymphocytes," Biochemical and Biophysical Research Communications, vol. 386, no. 4, pp. 682-687, 2009.

[8] J.-J. Yin, J. Liu, M. Ehrenshaft et al., "Phototoxicity of nano titanium dioxides in $\mathrm{HaCaT}$ keratinocytes-generation of reactive oxygen species and cell damage," Toxicology and Applied Pharmacology, vol. 263, no. 1, pp. 81-88, 2012.

[9] R. Zhang, Y. Niu, Y. Li et al., "Acute toxicity study of the interaction between titanium dioxide nanoparticles and lead acetate in mice," Environmental Toxicology and Pharmacology, vol. 30, no. 1, pp. 52-60, 2010.

[10] B. Jovanović and D. Palić, "Immunotoxicology of nonfunctionalized engineered nanoparticles in aquatic organisms with special emphasis on fish-review of current knowledge, gap identification, and call for further research," Aquatic Toxicology, vol. 118-119, pp. 141-151, 2012.

[11] N. A. Philbrook, L. M. Winn, A. R. M. N. Afrooz, N. B. Saleh, and V. K. Walker, "The effect of $\mathrm{TiO}_{2}$ and Ag nanoparticles on reproduction and development of Drosophila melanogaster and CD-1 mice," Toxicology and Applied Pharmacology, vol. 257, no. 3, pp. 429-436, 2011.

[12] F. Martínez-Gutierrez, E. P. Thi, J. M. Silverman et al., "Antibacterial activity, inflammatory response, coagulation and cytotoxicity effects of silver nanoparticles," Nanomedicine: Nanotechnology, Biology, and Medicine, vol. 8, no. 3, pp. 328-336, 2012.

[13] B. Sha, W. Gao, S. Wang, F. Xu, and T. Lu, "Cytotoxicity of titanium dioxide nanoparticles differs in four liver cells from human and rat," Composites Part B: Engineering, vol. 42, no. 8, pp. 2136-2144, 2011.

[14] A. Markowska-Szczupak, K. Ulfig, and A. W. Morawski, "The application of titanium dioxide for deactivation of bioparticulates: an overview," Catalysis Today, vol. 169, no. 1, pp. 249-257, 2011.

[15] S. Mohanty, S. Mishra, P. Jena, B. Jacob, B. Sarkar, and A. Sonawane, "An investigation on the antibacterial, cytotoxic, and antibiofilm efficacy of starch-stabilized silver nanoparticles," Nanomedicine: Nanotechnology, Biology, and Medicine, vol. 8, no. 6, pp. 916-924, 2012.

[16] I.-L. Hsiao and Y.-J. Huang, "Effects of various physicochemical characteristics on the toxicities of $\mathrm{ZnO}$ and $\mathrm{TiO}_{2}$ nanoparticles toward human lung epithelial cells," Science of the Total Environment, vol. 409, no. 7, pp. 1219-1228, 2011.

[17] M. A. Oosthuizen, H. M. Oberholzer, M. R. Scriba, W. J. van der Spuy, and E. Pretorius, "Evaluation of the morphological changes in the lungs of BALB/c mice after inhalation of spherical and rod-shaped titanium nanoparticles," Micron, vol. 43, no. 8, pp. 863-869, 2012.

[18] I. Bhatt and B. N. Tripathi, "Interaction of engineered nanoparticles with various components of the environment and possible strategies for their risk assessment," Chemosphere, vol. 82, no. 3, pp. 308-317, 2011.

[19] Y. Gao, N. V. Gopee, P. C. Howard, and L.-R. Yu, "Proteomic analysis of early response lymph node proteins in mice treated with titanium dioxide nanoparticles," Journal of Proteomics, vol. 74, no. 12, pp. 2745-2759, 2011.

[20] S. Jomini, H. Clivot, P. Bauda, and C. Pagnout, "Impact of manufactured $\mathrm{TiO}_{2}$ nanoparticles on planktonic and sessile bacterial communities," Environmental Pollution, vol. 202, pp. 196-204, 2015.

[21] J. Wu, J. Sun, and Y. Xue, "Involvement of JNK and P53 activation in G2/M cell cycle arrest and apoptosis induced by titanium dioxide nanoparticles in neuron cells," Toxicology Letters, vol. 199, no. 3, pp. 269-276, 2010.

[22] V. Iswarya, M. Bhuvaneshwari, S. A. Alex et al., "Combined toxicity of two crystalline phases (anatase and rutile) of Titania nanoparticles towards freshwater microalgae: Chlorella sp," Aquatic Toxicology, vol. 161, pp. 154-169, 2015.

[23] J. Chen, X. Dong, Y. Xin, and M. Zhao, "Effects of titanium dioxide nano-particles on growth and some histological parameters of zebrafish (Danio rerio) after a long-term exposure," Aquatic Toxicology, vol. 101, no. 3-4, pp. 493-499, 2011.

[24] S. Gui, Z. Zhang, L. Zheng et al., "Molecular mechanism of kidney injury of mice caused by exposure to titanium dioxide nanoparticles," Journal of Hazardous Materials, vol. 195, pp. 365-370, 2011.

[25] J. Wang, G. Zhou, C. Chen et al., "Acute toxicity and biodistribution of different sized titanium dioxide particles in mice after oral administration," Toxicology Letters, vol. 168, no. 2, pp. 176185, 2007. 
[26] Y. C. Hong, C. U. Bang, D. H. Shin, and H. S. Uhm, "Band gap narrowing of $\mathrm{TiO}_{2}$ by nitrogen doping in atmospheric microwave plasma," Chemical Physics Letters, vol. 413, no. 4-6, pp. 454-457, 2005.

[27] B. K. Bernard, M. R. Osheroff, A. Hofmann, and J. H. Mennear, "Toxicology and carcinogenesis studies of dietary titanium dioxide-coated mica in male and female fischer 344 rats," Journal of Toxicology and Environmental Health, vol. 29, no. 4, pp. 417-429, 1990.

[28] S. Hussain, S. Boland, A. Baeza-Squiban et al., "Oxidative stress and proinflammatory effects of carbon black and titanium dioxide nanoparticles: role of particle surface area and internalized amount," Toxicology, vol. 260, no. 1-3, pp. 142-149, 2009.

[29] D. B. Warheit, R. A. Hoke, C. Finlay, E. M. Donner, K. L. Reed, and C. M. Sayes, "Development of a base set of toxicity tests using ultrafine $\mathrm{TiO} 2$ particles as a component of nanoparticle risk management," Toxicology Letters, vol. 171, no. 3, pp. 99-110, 2007.

[30] I. Iavicoli, V. Leso, L. Fontana, and A. Bergamaschi, “Toxicological effects of titanium dioxide nanoparticles: a review of in vitro mammalian studies," European Review for Medical and Pharmacological Sciences, vol. 15, no. 5, pp. 481-508, 2011.

[31] I. Iavicoli, V. Leso, and A. Bergamaschi, "Toxicological effects of titanium dioxide nanoparticles: a review of in vivo studies," Journal of Nanomaterials, vol. 2012, Article ID 964381, 36 pages, 2012.

[32] J. Chen, X. Dong, J. Zhao, and G. Tang, "In vivo acute toxicity of titanium dioxide nanoparticles to mice after intraperitioneal injection," Journal of Applied Toxicology, vol. 29, no. 4, pp. 330337, 2009.

[33] R. K. Shukla, V. Sharma, A. K. Pandey, S. Singh, S. Sultana, and A. Dhawan, "ROS-mediated genotoxicity induced by titanium dioxide nanoparticles in human epidermal cells," Toxicology in Vitro, vol. 25, no. 1, pp. 231-241, 2011.

[34] Q. Sun, D. Tan, Y. Ze et al., "Pulmotoxicological effects caused by long-term titanium dioxide nanoparticles exposure in mice," Journal of Hazardous Materials, vol. 235-236, pp. 47-53, 2012.

[35] E.-J. Park, J. Yi, K.-H. Chung, D.-Y. Ryu, J. Choi, and K. Park, "Oxidative stress and apoptosis induced by titanium dioxide nanoparticles in cultured BEAS-2B cells," Toxicology Letters, vol. 180, no. 3, pp. 222-229, 2008.

[36] Y. Ze, L. Sheng, X. Zhao et al., " $\mathrm{TiO}_{2}$ nanoparticles induced hippocampal neuroinflammation in mice," PloS One, vol. 9, no. 3, Article ID e92230, 2014.

[37] Y. Shi, F. Wang, J. He, S. Yadav, and H. Wang, "Titanium dioxide nanoparticles cause apoptosis in BEAS-2B cells through the caspase 8/t-Bid-independent mitochondrial pathway," Toxicology Letters, vol. 196, no. 1, pp. 21-27, 2010.

[38] K. W. Ng, S. P. K. Khoo, B. C. Heng et al., "The role of the tumor suppressor $\mathrm{p} 53$ pathway in the cellular DNA damage response to zinc oxide nanoparticles," Biomaterials, vol. 32, no. 32, pp. 82188225, 2011.

[39] C. Migdal, R. Rahal, A. Rubod et al., "Internalisation of hybrid titanium dioxide/para-amino benzoic acid nanoparticles in human dendritic cells did not induce toxicity and changes in their functions," Toxicology Letters, vol. 199, no. 1, pp. 34-42, 2010.

[40] J. Sund, J. Palomäki, N. Ahonen, K. Savolainen, H. Alenius, and A. Puustinen, "Phagocytosis of nano-sized titanium dioxide triggers changes in protein acetylation," Journal of Proteomics, vol. 108, pp. 469-483, 2014.
[41] A. Zhu, K. Sun, and H. R. Petty, "Titanium doping reduces superoxide dismutase activity, but not oxidase activity, of catalytic CeO2 nanoparticles," Inorganic Chemistry Communications, vol. 15, pp. 235-237, 2012.

[42] X. Zhao, L. Sheng, L. Wang et al., "Mechanisms of nanosized titanium dioxide-induced testicular oxidative stress and apoptosis in male mice," Particle and Fibre Toxicology, vol. 11, article 47, 2014.

[43] B. Jovanović, L. Anastasova, E. W. Rowe, Y. Zhang, A. R. Clapp, and D. Palić, "Effects of nanosized titanium dioxide on innate immune system of fathead minnow (Pimephales promelas Rafinesque, 1820)," Ecotoxicology and Environmental Safety, vol. 74, no. 4, pp. 675-683, 2011.

[44] Q. Remijsen, T. W. Kuijpers, E. Wirawan, S. Lippens, P. Vandenabeele, and T. Vanden Berghe, "Dying for a cause: NETosis, mechanisms behind an antimicrobial cell death modality," Cell Death and Differentiation, vol. 18, no. 4, pp. 581-588, 2011.

[45] M. A. Mesa and G. Vasquez, "NETosis," Autoimmune Diseases, vol. 2013, Article ID 651497, 7 pages, 2013.

[46] ChemIDplus, ChemIDplus Advanced, Search Terms: Titanium Dioxide; CAS Reg. No. 13463-67-7, U.S. National Library of Medicine, National Institutes of Health, Department of Health and Human Services, 2005, http://chem.sis.nlm.nih.gov/ chemidplus/.

[47] R. Hu, L. Zheng, T. Zhang et al., "Molecular mechanism of hippocampal apoptosis of mice following exposure to titanium dioxide nanoparticles," Journal of Hazardous Materials, vol. 191, no. 1-3, pp. 32-40, 2011.

[48] M. Tu, Y. Huang, H.-L. Li, and Z.-H. Gao, "The stress caused by nitrite with titanium dioxide nanoparticles under UVA irradiation in human keratinocyte cell," Toxicology, vol. 299, no. 1, pp. 60-68, 2012.

[49] G. Paterson, J. M. Ataria, M. E. Hoque, D. C. Burns, and C. D. Metcalfe, "The toxicity of titanium dioxide nanopowder to early life stages of the Japanese medaka (Oryzias latipes)," Chemosphere, vol. 82, no. 7, pp. 1002-1009, 2011.

[50] Z. Chen, Y. Wang, T. Ba et al., "Genotoxic evaluation of titanium dioxide nanoparticles in vivo and in vitro," Toxicology Letters, vol. 226, no. 3, pp. 314-319, 2014

[51] Q. Saquib, A. A. Al-Khedhairy, M. A. Siddiqui, F. M. AbouTarboush, A. Azam, and J. Musarrat, "Titanium dioxide nanoparticles induced cytotoxicity, oxidative stress and DNA damage in human amnion epithelial (WISH) cells," Toxicology in Vitro, vol. 26, no. 2, pp. 351-361, 2012.

[52] B. Trouiller, R. Reliene, A. Westbrook, P. Solaimani, and R. H. Schiestl, "Titanium dioxide nanoparticles induce DNA damage and genetic instability in vivo in mice," Cancer Research, vol. 69, no. 22, pp. 8784-8789, 2009.

[53] V. Freyre-Fonseca, N. L. Delgado-Buenrostro, E. B. GutiérrezCirlos et al., "Titanium dioxide nanoparticles impair lung mitochondrial function," Toxicology Letters, vol. 202, no. 2, pp. 111-119, 2011.

[54] A. L. Di Virgilio, M. Reigosa, P. M. Arnal, and M. Fernández Lorenzo de Mele, "Comparative study of the cytotoxic and genotoxic effects of titanium oxide and aluminium oxide nanoparticles in Chinese hamster ovary (CHO-K1) cells," Journal of Hazardous Materials, vol. 177, no. 1-3, pp. 711-718, 2010.

[55] M. Ghosh, M. Bandyopadhyay, and A. Mukherjee, "Genotoxicity of titanium dioxide $\left(\mathrm{TiO}_{2}\right)$ nanoparticles at two trophic levels: plant and human lymphocytes," Chemosphere, vol. 81, no. 10, pp. 1253-1262, 2010. 
[56] G. Janer, E. Mas del Molino, E. Fernández-Rosas, A. Fernández, and S. Vázquez-Campos, "Cell uptake and oral absorption of titanium dioxide nanoparticles," Toxicology Letters, vol. 228, no. 2, pp. 103-110, 2014.

[57] E. Fröhlich and E. Roblegg, "Models for oral uptake of nanoparticles in consumer products," Toxicology, vol. 291, no. 1-3, pp. $10-17,2012$.

[58] J. Valant, D. Drobne, and S. Novak, "Effect of ingested titanium dioxide nanoparticles on the digestive gland cell membrane of terrestrial isopods," Chemosphere, vol. 87, no. 1, pp. 19-25, 2012.

[59] E. Brun, M. Carrière, and A. Mabondzo, "In vitro evidence of dysregulation of blood-brain barrier function after acute and repeated/long-term exposure to $\mathrm{TiO}_{2}$ nanoparticles," Biomaterials, vol. 33, no. 3, pp. 886-896, 2012.

[60] E. Huerta-García, J. A. Pérez-Arizti, S. G. Márquez-Ramírez et al., "Titanium dioxide nanoparticles induce strong oxidative stress and mitochondrial damage in glial cells," Free Radical Biology and Medicine, vol. 73, pp. 84-94, 2014.

[61] M. Naya, N. Kobayashi, M. Ema et al., "In vivo genotoxicity study of titanium dioxide nanoparticles using comet assay following intratracheal instillation in rats," Regulatory Toxicology and Pharmacology, vol. 62, no. 1, pp. 1-6, 2012.

[62] E.-J. Park, J. Yoon, K. Choi, J. Yi, and K. Park, "Induction of chronic inflammation in mice treated with titanium dioxide nanoparticles by intratracheal instillation," Toxicology, vol. 260, no. 1-3, pp. 37-46, 2009.

[63] S. Makumire, V. S. K. Chakravadhanula, G. Köllisch, E. Redel, and A. Shonhai, "Immunomodulatory activity of zinc peroxide $\left(\mathrm{ZnO}_{2}\right)$ and titanium dioxide $\left(\mathrm{TiO}_{2}\right)$ nanoparticles and their effects on DNA and protein integrity," Toxicology Letters, vol. 227, no. 1, pp. 56-64, 2014.

[64] J. Ahmad, S. Dwivedi, S. Alarifi, A. A. Al-Khedhairy, and J. Musarrat, "Use of $\beta$-galactosidase (lacZ) gene $\alpha$ complementation as a novel approach for assessment of titanium oxide nanoparticles induced mutagenesis," Mutation Research/Genetic Toxicology and Environmental Mutagenesis, vol. 747, no. 2, pp. 246-252, 2012.

[65] L. Sheng, L. Wang, X. Sang et al., "Nano-sized titanium dioxideinduced splenic toxicity: a biological pathway explored using microarray technology," Journal of Hazardous Materials, vol. 278, pp. 180-188, 2014.

[66] J. J. Wang, B. J. S. Sanderson, and H. Wang, "Cyto- and genotoxicity of ultrafine $\mathrm{TiO}_{2}$ particles in cultured human lymphoblastoid cells," Mutation Research/Genetic Toxicology and Environmental Mutagenesis, vol. 628, no. 2, pp. 99-106, 2007.

[67] D. B. Warheit, C. M. Sayes, K. L. Reed, and K. A. Swain, "Health effects related to nanoparticle exposures: environmental, health and safety considerations for assessing hazards and risks," Pharmacology and Therapeutics, vol. 120, no. 1, pp. 35-42, 2008.

[68] Y. Wang, P. Westerhoff, and K. D. Hristovski, "Fate and biological effects of silver, titanium dioxide, and $\mathrm{C}_{60}$ (fullerene) nanomaterials during simulated wastewater treatment processes," Journal of Hazardous Materials, vol. 201-202, pp. 16-22, 2012.

[69] N. B. Hartmann, S. Legros, F. Von der Kammer, T. Hofmann, and A. Baun, "The potential of $\mathrm{TiO}_{2}$ nanoparticles as carriers for cadmium uptake in Lumbriculus variegatus and Daphnia magna," Aquatic Toxicology, vol. 118-119, pp. 1-8, 2012.

[70] C. S. Ramsden, T. B. Henry, and R. D. Handy, "Sub-lethal effects of titanium dioxide nanoparticles on the physiology and reproduction of zebrafish," Aquatic Toxicology, vol. 126, pp. 404413, 2013.
[71] M. Ates, V. Demir, R. Adiguzel, and Z. Arslan, "Bioaccumulation, subacute toxicity, and tissue distribution of engineered titanium dioxide nanoparticles in goldfish (Carassius auratus)," Journal of Nanomaterials, vol. 2013, Article ID 460518, 6 pages, 2013.

[72] L. Hao, Z. Wang, and B. Xing, "Effect of sub-acute exposure to $\mathrm{TiO}_{2}$ nanoparticles on oxidative stress and histopathological changes in Juvenile Carp (Cyprinus carpio)," Journal of Environmental Sciences, vol. 21, no. 10, pp. 1459-1466, 2009.

[73] S. H. Bang, T.-H. Le, S. K. Lee, P. Kim, J. S. Kim, and J. Min, "Toxicity assessment of titanium (IV) oxide nanoparticles using Daphnia magna (Water Flea)," Environmental Health and Toxicology, vol. 26, Article ID e2011002, 2011.

[74] C. Srisitthiratkul, V. Pongsorrarith, and N. Intasanta, "The potential use of nanosilver-decorated titanium dioxide nanofibers for toxin decomposition with antimicrobial and self-cleaning properties," Applied Surface Science, vol. 257, no. 21, pp. 8850-8856, 2011.

[75] R. Govindasamy and A. A. Rahuman, "Histopathological studies and oxidative stress of synthesized silver nanoparticles in Mozambique tilapia (Oreochromis mossambicus)," Journal of Environmental Sciences (China), vol. 24, no. 6, pp. 1091-1098, 2012.

[76] C.-M. Liao, Y.-H. Chiang, and C.-P. Chio, "Assessing the airborne titanium dioxide nanoparticle-related exposure hazard at workplace," Journal of Hazardous Materials, vol. 162, pp. 57-65, 2009.

[77] D. Zheng, N. Wang, X. Wang et al., "Effects of the interaction of $\mathrm{TiO}_{2}$ nanoparticles with bisphenol A on their physicochemical properties and in vitro toxicity," Journal of Hazardous Materials, vol. 199-200, pp. 426-432, 2012.

[78] N. B. Hartmann, F. Von der Kammer, T. Hofmann, M. Baalousha, S. Ottofuelling, and A. Baun, "Algal testing of titanium dioxide nanoparticles-testing considerations, inhibitory effects and modification of cadmium bioavailability," Toxicology, vol. 269, no. 2-3, pp. 190-197, 2010.

[79] Q. Chen, D. Yin, S. Zhu, and X. Hu, "Adsorption of cadmium(II) on humic acid coated titanium dioxide," Journal of Colloid and Interface Science, vol. 367, no. 1, pp. 241-248, 2012.

[80] J. Hu and H. J. Shipley, "Evaluation of desorption of $\mathrm{Pb}$ (II), $\mathrm{Cu}$ (II) and Zn (II) from titanium dioxide nanoparticles," Science of the Total Environment, vol. 431, pp. 209-220, 2012.

[81] B. Jovanović, T. Ji, and D. Palić, "Gene expression of zebrafish embryos exposed to titanium dioxide nanoparticles and hydroxylated fullerenes," Ecotoxicology and Environmental Safety, vol. 74, no. 6, pp. 1518-1525, 2011.

[82] A. Menard, D. Drobne, and A. Jemec, "Ecotoxicity of nanosized $\mathrm{TiO}_{2}$. Review of in vivo data," Environmental Pollution, vol. 159, no. 3, pp. 677-684, 2011.

[83] D. Drobne, A. Jemec, and Ž. Pipan Tkalec, "In vivo screening to determine hazards of nanoparticles: nanosized $\mathrm{TiO}_{2}$," Environmental Pollution, vol. 157, no. 4, pp. 1157-1164, 2009.

[84] G. Federici, B. J. Shaw, and R. D. Handy, "Toxicity of titanium dioxide nanoparticles to rainbow trout (Oncorhynchus mykiss): gill injury, oxidative stress, and other physiological effects," Aquatic Toxicology, vol. 84, no. 4, pp. 415-430, 2007.

[85] J. Unnithan, M. U. Rehman, F. J. Ahmad, and M. Samim, "Concentration dependent toxicity of $\sim 20 \mathrm{~nm}$ anatase titanium dioxide nanoparticles-an in vivo study on wistar rats," Journal of Biomedical Nanotechnology, vol. 7, no. 1, pp. 207-208, 2011.

[86] R. Posgai, C. B. Cipolla-McCulloch, K. R. Murphy, S. M. Hussain, J. J. Rowe, and M. G. Nielsen, "Differential toxicity 
of silver and titanium dioxide nanoparticles on Drosophila melanogaster development, reproductive effort, and viability: size, coatings and antioxidants matter," Chemosphere, vol. 85, no. 1, pp. 34-42, 2011.

[87] A. Lankoff, W. J. Sandberg, A. Wegierek-Ciuk et al., "The effect of agglomeration state of silver and titanium dioxide nanoparticles on cellular response of HepG2, A549 and THP1 cells," Toxicology Letters, vol. 208, no. 3, pp. 197-213, 2012.

[88] A. García, R. Espinosa, L. Delgado et al., "Acute toxicity of cerium oxide, titanium oxide and iron oxide nanoparticles using standardized tests," Desalination, vol. 269, no. 1-3, pp.136141, 2011.

[89] F. von der Kammer, S. Ottofuelling, and T. Hofmann, "Assessment of the physico-chemical behavior of titanium dioxide nanoparticles in aquatic environments using multidimensional parameter testing," Environmental Pollution, vol. 158, no. 12, pp. 3472-3481, 2010.

[90] N. Asare, C. Instanes, W. J. Sandberg et al., "Cytotoxic and genotoxic effects of silver nanoparticles in testicular cells," Toxicology, vol. 291, no. 1-3, pp. 65-72, 2012. 

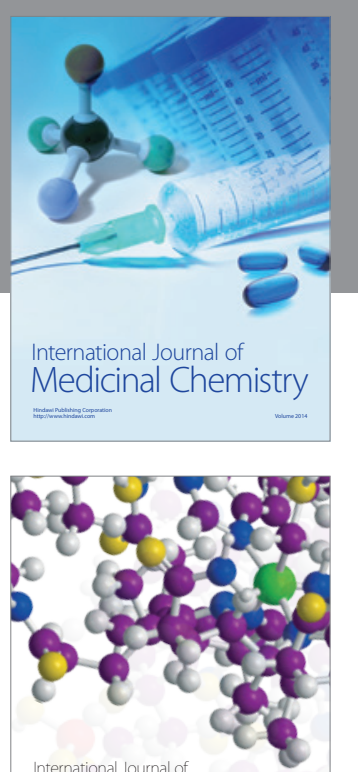

Carbohydrate Chemistry

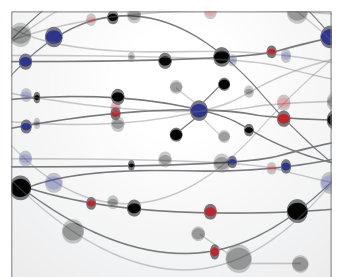

The Scientific World Journal
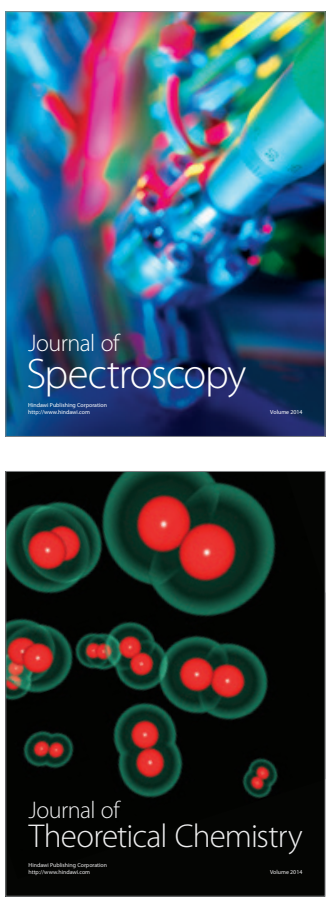
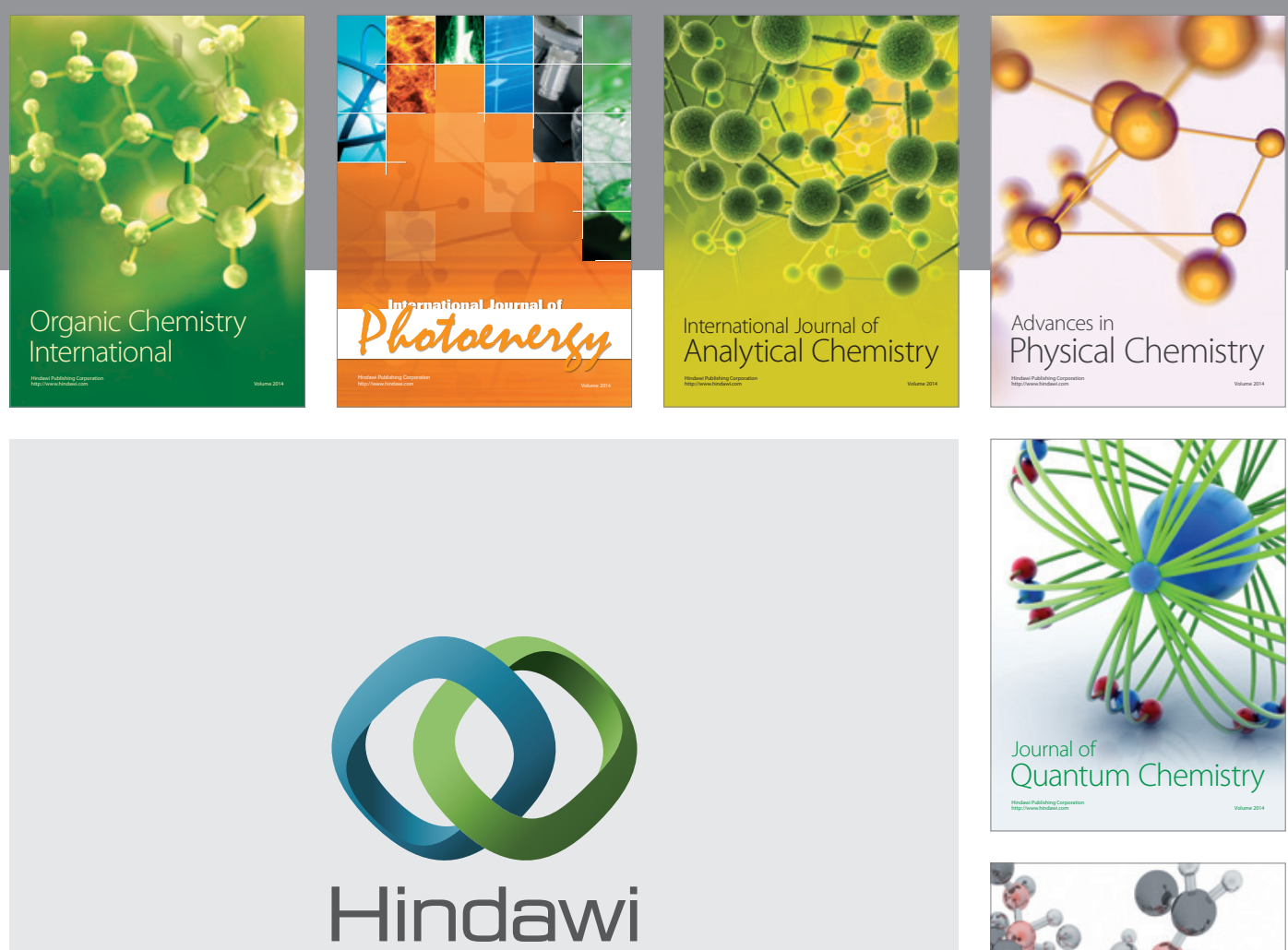

Submit your manuscripts at

https://www.hindawi.com

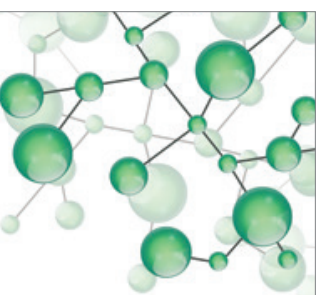

International Journal of

Inorganic Chemistry
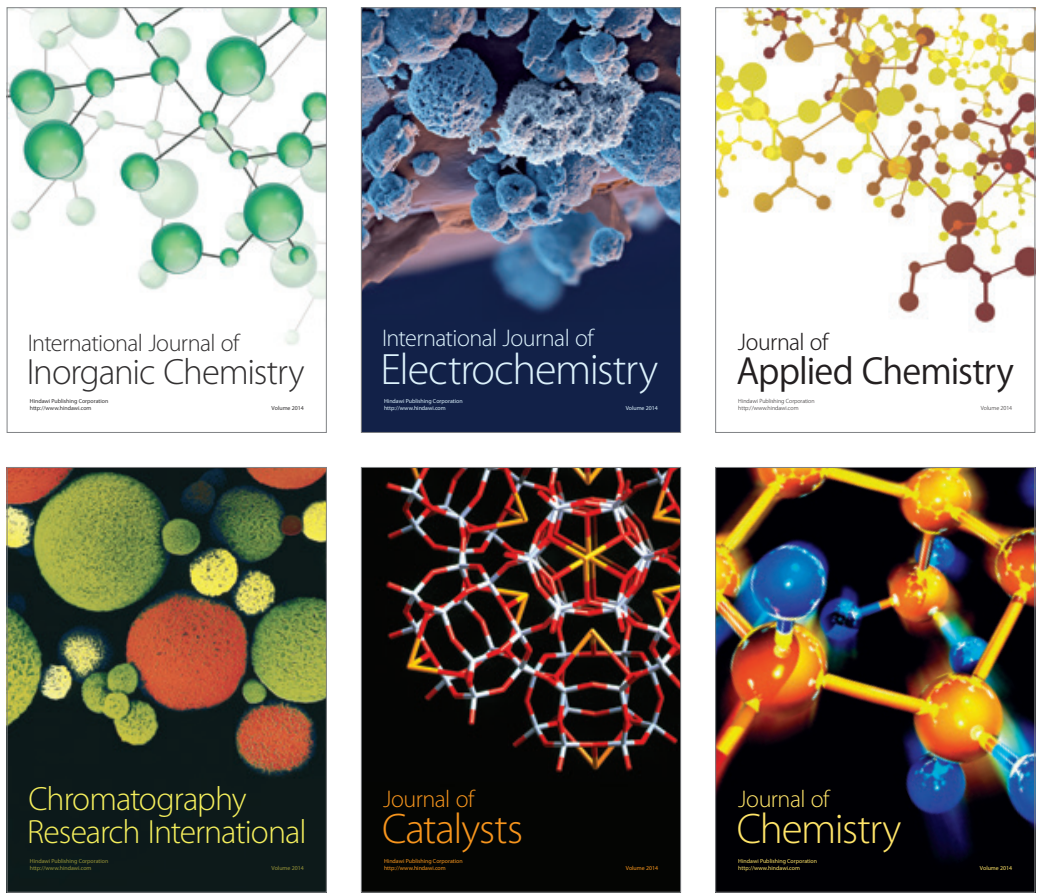

Journal of

Applied Chemistry
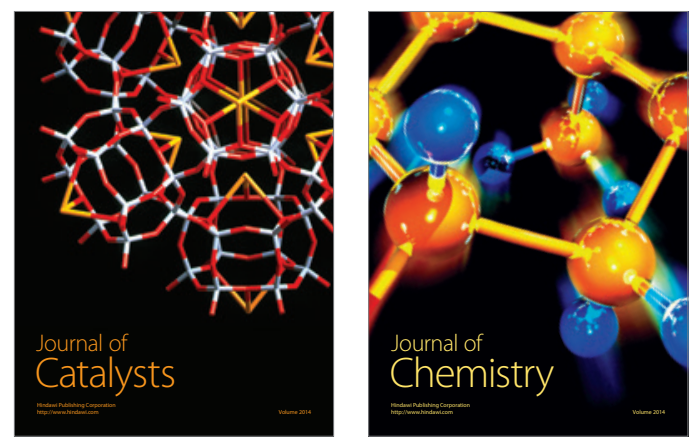
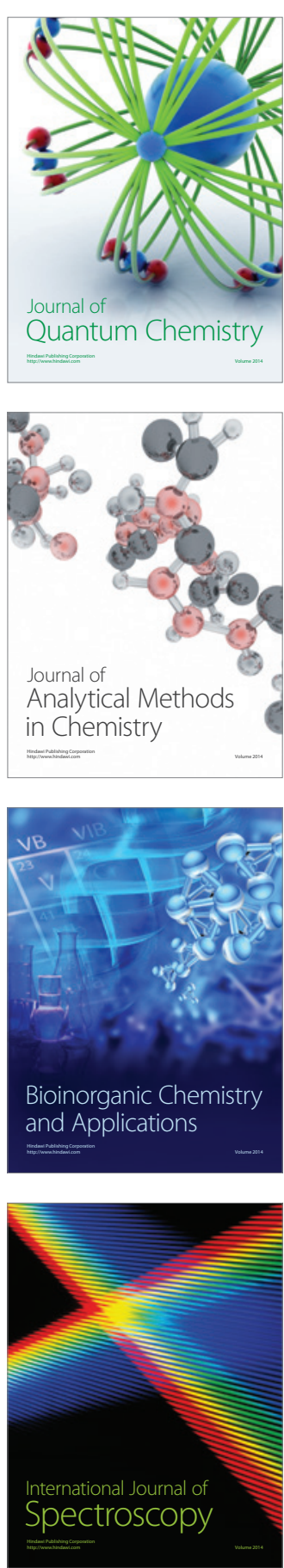